\title{
Development of PCR-Based Assays for Detecting and Differentiating Three Species of Botrytis Infecting Broad Bean
}

Xuan Fan, Jing Zhang, Long Yang, Mingde Wu, State Key Laboratory of Agricultural Microbiology and Key Laboratory of Plant Pathology of Hubei Province, Huazhong Agricultural University, Wuhan 430070, China; Weidong Chen, United States Department of AgricultureAgricultural Research Service, Washington State University, Pullman; and Guoqing Li, State Key Laboratory of Agricultural Microbiology and Key Laboratory of Plant Pathology of Hubei Province, Huazhong Agricultural University

\begin{abstract}
Fan, X., Zhang, J., Yang, L., Wu, M., Chen, W., and Li, G. 2015. Development of PCR-Based assays for detecting and differentiating three species of Botrytis infecting broad bean. Plant Dis. 99:691-698.

Botrytis cinerea, B. fabae, and B. fabiopsis are known to cause chocolate spot on broad bean. This study was conducted to develop polymerase chain reaction (PCR)-based assays to detect and differentiate these three species. Two sets of primers, Bc-f/Bc-r for B. cinerea and Bfab-f/Bfab-r for B. fabiopsis, were designed based on two sequence-characterized amplified region markers derived from two random amplified polymorphic DNA assays. The other primer set, Bfa-f/Bfa-r for B. fabae, was designed based on the necrosis and ethylene-inducing protein 1 gene sequence. The three primer sets were highly specific for the corresponding species of Botrytis in

both single and multiplex PCR assays. The PCR detection limit was 40, 40, and 400 pg of DNA per $25-\mu 1$ reaction mixture for B. fabae, B. fabiopsis, and $B$. cinerea, respectively. Presence of the broad bean DNA in the PCR reactions at 1:1000 (Botrytis DNA/broad bean DNA [wt/wt]) had negligible effects on detection of the targeted Botrytis spp. The multiplex PCR assay was able to detect three Botrytis spp. in artificially infected and naturally infected broad bean leaves. These results suggest that the multiplex PCR assay developed in this study could be used to monitor the epidemics of chocolate spot of broad bean in the field.
\end{abstract}

Chocolate spot, caused by Botrytis spp., is one of the most important foliar diseases of broad bean (Vicia faba L.) worldwide (Gourley and Delbridge 1973; Harrison 1988; Yu 1945). It can severely reduce plant growth of broad bean and decrease seed production of this crop by $50 \%$ or more under humid and cool weather conditions (Harrison 1988; Soper 1952; Yu 1945). Chocolate spot of broad bean is a polycyclic airborne disease. The initial source of inoculum is conidia produced on infested broad bean residue of the previous crop (Harrison 1988; Yu 1945). The conidia are dispersed by air to the tissues of broad bean plants (e.g., leaves, stems, flowers, and pods), where they germinate when conditions are warm $\left(20^{\circ} \mathrm{C}\right)$ and humid (greater than $98 \%$ relative humidity). Infection of host tissues by the pathogen is facilitated by phytotoxins (e.g., botrytone) and cell-wall-degrading enzymes (e.g., polygalacturonase). Characteristic rust-colored spots develop and conidia are subsequently produced and act as the secondary infection source to initiate another round of infection (Harrison 1988).

Two species of Botrytis are recognized to cause chocolate spot on broad bean: Botrytis cinerea Pers. (teleomorph: Botryotinia fuckeliana (de Bary) Whetzel) and Botrytis fabae Sardiña (teleomorph: Botryotinia fabae J. Y. Lu \& T. H. Wu) (Harrison 1988; Wilson 1937; Yu 1945). The species differ greatly in preference for infecting broad bean tissues: Botrytis cinerea can be found primarily on floral parts, whereas B. fabae usually is found in leaves, stems, and pods (Harrison 1988; Yu 1945). Recently, Zhang and coworkers (2010a) described a novel species of Botrytis (B. fabiopsis J. Zhang, M. D. Wu \& G. Q. Li) on broad bean in Hubei Province of central China. Although B. fabiopsis causes leaf symptoms similar to those caused by $B$. fabae, it differs from $B$. fabae and other Botrytis spp. in morphological characteristics (colonies, conidia, and sclerotia) and phylogenetic status (Zhang et al. 2010a). A recent

Corresponding author: J. Zhang; E-mail: zhangjing1007@mail.hzau.edu.cn

* The $\boldsymbol{e}$-Xtra logo stands for "electronic extra" and indicates that three supplementary figures are published online.

Accepted for publication 9 December 2014.

http://dx.doi.org/10.1094/PDIS-07-14-0701-RE

(C) 2015 The American Phytopathological Society study by Huang and coworkers (2012) showed that the three Botrytis spp. are widely distributed on broad bean in six other provinces in China, including Chongqing, Gansu, Hebei, Jiangsu, Qinghai, and Sichuan.

Currently, diagnosis of B. cinerea, B. fabae, and B. fabiopsis on broad bean is mainly based on visual assessment of disease symptoms and by isolation or identification of the pathogens from diseased plant tissues (Huang et al. 2012; Wilson 1937; Yu 1945). This procedure is time consuming and labor intensive, and requires expertise. Identification of the causal Botrytis spp. for chocolate spot of broad bean is important because the three species have different temperature optima and different sensitivities to fungicides and, consequently, they may require different management practices.

Numerous studies indicated that polymerase chain reaction (PCR)based methods are useful for detecting $B$. cinerea either qualitatively or quantitatively (Celik et al. 2009; Chen et al. 1998; Diguta et al. 2010; Gachon and Saindrenan 2004; Gindro et al. 2005; Mehli et al. 2005; Suarez et al. 2005; Tomlinson et al. 2010). Rigotti et al. (2002, 2006) developed two $B$. cinerea-specific primer sets $\left(\mathrm{C}_{729}{ }^{+} / \mathrm{C}_{729}{ }^{-}\right.$and $\mathrm{BC}_{108}{ }^{+} / \mathrm{BC}_{563}{ }^{-}$) based on a sequence-characterized amplified region (SCAR) marker derived from a random amplified polymorphic DNA (RAPD) assay. The primer set $\mathrm{C}_{729}{ }^{+} / \mathrm{C}_{729}{ }^{-}$has been successfully used to detect $B$. cinerea in symptomless strawberry plants (Rigotti et al. 2002), in immature grape berries (Gindro et al. 2005), and in diseased tomato fruit (Wang et al. 2007). PCR-based detection has also been developed for other species of Botrytis. Chilvers et al. (2007) developed a real-time PCR assay for quantification of B. aclada, B. allii, and $B$. byssoidea in onion seed. The primer set LR12R/CNS1 used in that assay was based on sequence variations in the nuclear ribosomal intergenic spacer (IGS) region. It could detect $B$. aclada, $B$. allii, and $B$. byssoidea but was unable to detect $B$. cinerea, $B$. porri, $B$. squamosa, Sclerotinia sclerotiorum, and 15 other fungal species from onion seed. Chilvers et al. (2007) further indicated that the real-time PCR assay exhibited higher efficiency than the conventional plating assay on agar media in detecting the three Botrytis spp. in onion seed. Carisse et al. (2009) developed a TaqMan real-time PCR assay using the primer set B_squa_up221/B_squa_lo361 based on the RPB2 gene (coding for RNA polymerase II) for quantification of the airborne conidia of B. squamosa, the causal agent of Botrytis leaf blight of onion.

In molecular differentiation and identification of Botrytis spp., Staats et al. (2005) showed that sequences of three nuclear genes-namely, 
glyceraldehyde-3-phosphate dehydrogenase $(G 3 P D H)$, heat-shock protein 60 (HSP60), and RNA polymerase II (RPB2) - provide sufficient variation to support morphological delimitation of 22 species in the genus Botrytis proposed by Hennebert (1973). DNA sequences of these three nuclear genes have been successfully used as supporting evidence in description of novel Botrytis spp. such as B. fabiopsis J. Zhang, M. D. Wu \& G. Q. Li sp. nov. (Zhang et al. 2010a), B. sinoallii J. Zhang, G. Q. Li \& W. Y. Zhuang sp. nov. (Zhang et al. 2010b), and B. sinoviticola J. Zhang, Y. J. Zhou \& G. Q. Li sp. nov. (Zhou et al. 2014). In addition, Mirzaei and coworkers (2008) reported that the necrosis and ethylene-inducing protein (NEP) primer set $\mathrm{NEP}^{+} / \mathrm{NEP} 2^{-}$, designed on the basis of the DNA sequence of the NEP2 gene, could distinguish B. cinerea, B. fabae, and B. pelargonii from B. aclada, $B$. convoluta, B. gladiolorum, B. paeoniae, and B. porri. Zhang et al. (2010a) reported that combined use of the primer sets NEP1for/NEP1revB (Staats et al. 2007) and NEP2 ${ }^{+} / \mathrm{NEP}^{-}{ }^{-}$(Mirzaei et al. 2008) could distinguish B. cinerea, B. fabae, and B. fabiopsis. However, information about the PCR assays for in planta detection of B. cinerea, B. fabae, and B. fabiopsis is not available in the literature. The objective of this study was to design species-specific PCR primers that could be used to differentiate $B$. cinerea, B. fabae, and B. fabiopsis, and detect in planta infection by these Botrytis spp.

\section{Materials and Methods}

Fungal isolates. In total, 63 fungal isolates were used in this study (Table 1). They included 29 isolates of $B$. cinerea, 8 isolates of B. fabae, 8 isolates of B. fabiopsis, 10 isolates of other eight species of Botrytis, 2 isolates of two Botrytis-like genera (Amphobotrys [Amphobotrys ricini] and Streptobotrys), and 6 isolates of other five saprophytic fungi isolated from broad bean leaves. The diversity of the $B$. cinerea isolates used in this study was assessed by detecting the presence or absence of the transposable elements Boty and Flipper in their genomes, as described by Samuel and coworkers (2012). All the isolates were long-term stored at $-80^{\circ} \mathrm{C}$ in $20 \%$ glycerol (vol/vol). Working cultures of each isolate were established by transferring stock mycelial agar plugs onto potato dextrose agar (PDA) plates, which were incubated at $20^{\circ} \mathrm{C}$ in the dark for 7 to 10 days.

DNA isolation. Total genomic DNA was isolated from a mycelial mat of each isolate harvested from 2-day-old cultures on PDA overlaid with sterile cellophane films, using the minipreparation procedure described by Möller and coworkers (1992). Total DNA was also isolated from healthy or diseased leaves of broad bean ( $V$. faba), using the Plant Genomic DNA Kit (DP305; TIANGEN BiotechBeijing Co., Ltd., Beijing) according to the manufacturer's instructions. DNA was dissolved in Tris-EDTA buffer, and DNA concentration was determined in a NANODROP 2000 UV-Vis spectrophotometer (Thermo Fisher Scientific Inc., Wilmington, DE).

Primer design. The SCAR marker strategy was used to design species-specific primers. Three isolates of B. cinerea $(\mathrm{BC}-1, \mathrm{BC}-15$, and $\mathrm{BC}-27$ ), three isolates of $B$. fabae (BC-17, BC-22, and BC-25), and three isolates of $B$. fabiopsis (BC-2, BC-13, and BC-30) (Table 1) were used in the RAPD assays with the two 10-mer Operon primers, OPA-13 and OPE-11 (Beijing AuGCT DNA-SYN Biotechnology Co., Beijing). The PCR amplifications were done using a program described previously (Rigotti et al. 2002). The amplification products were separated on a $1 \%$ agarose gel in Tris-borate-EDTA buffer $(89 \mathrm{mM}$ Tris, $89 \mathrm{mM}$ boric acid, and $2 \mathrm{mM}$ EDTA) and visualized on an UV transilluminator after staining with ethidium bromide $(1.5 \mathrm{mg} / \mathrm{ml})$. Two DNA bands of different size specific to B. cinerea and B. fabiopsis (Supplementary Fig. S1) were individually excised from the agarose gels and purified using AxyPrep DNA Gel Extraction Kit (Axygen Scientific, Inc., Union City, CA), cloned into Escherichia coli DH5 $\alpha$ using the pMD18-T vector (TaKaRa), and sequenced in Beijing AuGCT Biotechnology Co. Ltd. The primer sets designated as Bc-f/Bc-r and Bfab-f/ Bfab-r for B. cinerea and B. fabiopsis, respectively, were designed on the basis of the SCAR marker sequences for the two fungal species, respectively (Supplementary Fig. S2; Table 2). Unfortunately, no reliable RAPD bands specific to $B$. fabae was detected with this strategy.

In order to design a primer set specific to $B$. fabae, the partial sequences of five nuclear genes, including G3PDH, HSP60, RPB2,
$N E P 1$, and $N E P 2$, from B. cinerea, B. fabae, and B. fabiopsis (Zhang et al. 2010a) were aligned using the DNAMAN software (version 5.2.2; Lynnon Corp., Vaudreuil, Quebec, Canada). The nucleotide differences in the aligned sequences for each gene were identified. A primer set designated as Bfa-f/Bfa-r targeting the NEP1 gene was obtained (Supplementary Fig. S3; Table 2). All the newly designed primer sets were synthesized at the Beijing AuGCT DNA-SYN Biotechnology Company, and were used in subsequent assays to test their specificity, sensitivity (PCR detection limit), and practicability.

Evaluation of primer specificity. Four experiments were done to test specificity of the primer sets in detecting B. cinerea, B. fabae, and B. fabiopsis. The first experiment consisted of a single primer-set assay (single PCR or conventional PCR). In total, 24 isolates of B. cinerea (8 isolates), B. fabae ( 8 isolates), and B. fabiopsis ( 8 isolates) were included. Each $25-\mu 1$ PCR mixture contained $2.5 \mu$ l of $10 \times$ PCR buffer, $0.5 \mu$ l of dNTP $(2.5 \mathrm{mM}), 1.25 \mathrm{U}$ of rTaq DNA polymerase $(0.25 \mu \mathrm{l}$, TaKaRa), $0.5 \mu \mathrm{l}$ of each of two primers $(20 \mu \mathrm{M})$, $1 \mu \mathrm{l}$ of template DNA of a Botrytis isolate (40 $\mathrm{ng} / \mu \mathrm{l})$, and $19.75 \mu \mathrm{l}$ of double-distilled (dd) $\mathrm{H}_{2} \mathrm{O}$. A PCR mixture without addition of any template DNA was used as the negative control. The PCR was programmed as follows (conventional PCR program): denaturation at $94^{\circ} \mathrm{C}$ for $5 \mathrm{~min} ; 27$ cycles of $94^{\circ} \mathrm{C}$ for $30 \mathrm{~s}, 62^{\circ} \mathrm{C}$ for $30 \mathrm{~s}$, and $72^{\circ} \mathrm{C}$ for $1 \mathrm{~min}$; and final extension at $72^{\circ} \mathrm{C}$ for $10 \mathrm{~min}$. An aliquot of $15 \mu$ l of PCR mixture was subject to electrophoresis in $1 \%$ agarose gel (wt/vol) and viewed on an UV transilluminator after staining with ethidium bromide $(1.5 \mathrm{mg} / \mathrm{ml})$. The PCR was repeated three times in this experiment and in each of the remaining experiments or assays mentioned below.

The second experiment was also a single PCR assay with the mixed DNA of B. cinerea, B. fabae, and B. fabiopsis as template. Preparation of the 25- $\mu$ l PCR mixtures for each primer set was similar to that mentioned above, except that the DNA template consisted of mixed DNA of the three species of Botrytis. In total, $120 \mathrm{ng}$ of DNA was added to each PCR mixture: $40 \mathrm{ng}$ from $B$. cinerea isolate $\mathrm{BC}-1,40 \mathrm{ng}$ from $B$. fabae isolate $\mathrm{BC}-17$, and $40 \mathrm{ng}$ from B. fabiopsis isolate BC-30. A PCR mixture without addition of any DNA template was used as control. The PCR and detection of the PCR products were performed using the procedures described previously.

The third experiment was a multiple primer-set PCR assay (multiplex PCR). B. cinerea isolate BC-1, B. fabae isolate BC-17, and B. fabiopsis isolate BC-30 were used in this experiment. Each $25-\mu \mathrm{l}$ PCR mixture contained $2.5 \mu \mathrm{l}$ of $10 \times$ PCR buffer, $1.5 \mu \mathrm{l}$ of dNTPs $(2.5 \mathrm{mM}), 1.25 \mathrm{U}$ of rTaq DNA polymerase ( $0.25 \mu \mathrm{l}$, TaKaRa), $6 \times$ $0.5 \mu \mathrm{l}$ of each primer $(20 \mu \mathrm{M}), 3 \mu \mathrm{l}$ of template DNA solution ( $1 \mu \mathrm{l}$ for each isolate, $120 \mathrm{ng}$ of DNA in total), and $14.75 \mu \mathrm{l}$ of $\mathrm{ddH}_{2} \mathrm{O}$. A PCR mixture identical to that described above but lacking DNA was used as the negative control. Meanwhile, single PCR mixtures containing the mixed primer sets and each template DNA were performed as positive controls. The PCR was carried out using the conventional PCR program and the resulting PCR products were separated and detected by agarose gel electrophoresis, as described above.

The fourth experiment was also a multiplex PCR assay aiming at detecting 21 isolates of $B$. cinerea from 21 other plant species, 10 isolates of another 8 species of Botrytis, 2 isolates of the Botrytis-like genera Amphobotrys (A. ricini) and Streptobotrys, and 6 isolates of five other fungi isolated from leaves of broad bean (Table 1). Each 25- $\mu$ l PCR mixture contained $2.5 \mu l$ of $10 \times$ PCR buffer, $1.5 \mu l$ of dNTPs $(2.5 \mathrm{mM}), 1.25 \mathrm{U}$ of rTaq DNA polymerase $(0.25 \mu \mathrm{l}$, TaKaRa), $6 \times 0.5 \mu$ l of each primer $(20 \mu \mathrm{M}), 1 \mu \mathrm{l}(40 \mathrm{ng})$ of template DNA, and $16.75 \mu \mathrm{l}$ of $\mathrm{ddH}_{2} \mathrm{O}$. A multiplex PCR mixture without addition of any template DNA was used as the negative control. The PCR was performed using the conventional PCR program and the resulting PCR products were detected by agarose gel electrophoresis.

Determination of the PCR detection limit. Three fungal isolates (BC-1 of B. cinerea, BC-17 of B. fabae, and BC-30 of B. fabiopsis) were used in this single PCR assay. For each Botrytis isolate, there were seven $25-\mu 1$ PCR mixtures containing the template DNA at 0 , $0.04,0.4,0.8,4.0,20.0$, and $40.0 \mathrm{ng}$ per reaction, respectively. A PCR mixture without addition of any template DNA was treated as the negative control. The PCR was performed using the conventional 
Table 1. Fungal isolates used in this study, presence of transposable element, and selected polymerase chain reaction (PCR) markers for distinguishing Botrytis cinerea, B. fabae, and B. fabiopsis

\begin{tabular}{|c|c|c|c|c|c|c|}
\hline \multirow[b]{2}{*}{ Species } & \multirow[b]{2}{*}{ Isolate } & \multirow[b]{2}{*}{ Transposable element ${ }^{b}$} & \multirow[b]{2}{*}{ Origin (host, location, year) } & \multicolumn{3}{|c|}{ PCR marker ${ }^{a}$} \\
\hline & & & & 327-bp & 613-bp & $762-b p$ \\
\hline \multirow[t]{29}{*}{ B. cinerea } & BC-1 & Flipper & Broad bean, Wuhan (Hubei), 2005 & + & - & - \\
\hline & BC-15 & Boty + Flipper & Broad bean, Xian Ning (Hubei), 2007 & + & - & - \\
\hline & BC-27 & Boty + Flipper & Broad bean, Ba Dong (Hubei), 2007 & + & - & - \\
\hline & BC-60 & Boty + Flipper & Broad bean, E Zhou (Hubei), 2008 & + & - & - \\
\hline & BC-70 & Boty + Flipper & Broad bean, Xiang Yang (Hubei), 2008 & + & - & - \\
\hline & BC-72 & Boty & Broad bean, Huang Mei (Hubei), 2008 & + & - & - \\
\hline & BC-96 & Boty + Flipper & Broad bean, Qi Chun (Hubei), 2008 & + & - & - \\
\hline & BC-103 & Boty + Flipper & Broad bean, Huang Gang (Hubei), 2009 & + & - & - \\
\hline & TulBC-4 & Boty + Flipper & Tulip, Wuhan (Hubei), 2011 & + & - & - \\
\hline & LacBC-6 & Flipper & Lettuce, Shi Yan (Hubei), 2011 & + & - & - \\
\hline & BraBC-2 & Flipper & Chinese cabbage, Shi Yan (Hubei), 2011 & + & - & - \\
\hline & GBC-31 & Boty + Flipper & Grape, Xinjiang, 2011 & + & - & - \\
\hline & PeoBC-12 & Flipper & Peony, Wuhan(Hubei), 2011 & + & - & - \\
\hline & BluBC-10 & Boty & Blueberry, Wuhan (Hubei), 2012 & + & - & - \\
\hline & OniBC-129 & Flipper & Green onion, Shi Yan (Hubei), 2009 & + & - & - \\
\hline & GarBC-132 & Flipper & Garlic, Shi Yan (Hubei), 2009 & + & - & - \\
\hline & RoseBC-3 & Boty + Flipper & Rose, Wuhan (Hubei), 2004 & + & - & - \\
\hline & PeaBC-1 & vacuma & Peach, Wuhan (Hubei), 2008 & + & - & - \\
\hline & VioBC-1 & Flipper & Pansy, Wuhan (Hubei), 2008 & + & - & - \\
\hline & PeaBC-10 & Flipper & Pea, Jiang Xi, 2012 & + & - & - \\
\hline & BerBC-1 & vacuma & Berberis, Wuhan (Hubei), 2008 & + & - & - \\
\hline & WBC-3 & Flipper & Wheat, Wuhan (Hubei), 2006 & + & - & - \\
\hline & CitBC-1 & Flipper & Watermelon, Wuhan (Hubei), 2009 & + & - & - \\
\hline & PearBC-1 & vacuma & Pear, Xian Feng (Hubei), 2007 & + & - & - \\
\hline & sBC-70 & Boty + Flipper & Strawberry, Wuhan (Hubei), 2012 & + & - & - \\
\hline & $\mathrm{tBC}-87$ & Boty + Flipper & Tomato, Ma Cheng (Hubei), 2012 & + & - & - \\
\hline & GlaBC-1 & Flipper & Gladiolus, Li Chuan (Hubei), 2007 & + & - & - \\
\hline & CanBC-7 & Flipper & Oilseed rape, Xiao Gan (Hubei), 2006 & + & - & - \\
\hline & LHK-11 & Boty + Flipper & Pepper, Shi Yan (Hubei), 2012 & + & - & - \\
\hline \multirow[t]{8}{*}{ B. fabae } & BC-17 & ND & Broad bean, Yi Du (Hubei), 2007 & - & - & + \\
\hline & BC-22 & ND & Broad bean, Xuan En (Hubei), 2007 & - & - & + \\
\hline & BC-25 & ND & Broad bean, Xiang Yang (Hubei), 2007 & - & - & + \\
\hline & BF-63 & ND & Broad bean, E Zhou (Hubei), 2008 & - & - & + \\
\hline & BF-100 & ND & Broad bean, Wu Xue (Hubei), 2009 & - & - & + \\
\hline & BF-109 & ND & Broad bean, Hong Hu (Hubei), 2009 & - & - & + \\
\hline & BF-120 & ND & Broad bean, Gong An (Hubei), 2009 & - & - & + \\
\hline & BF-136 & ND & Broad bean, Hong An (Hubei), 2009 & - & - & + \\
\hline \multirow[t]{8}{*}{ B. fabiopsis } & $\mathrm{BC}-2$ & ND & Broad bean, Wuhan (Hubei), 2006 & - & + & - \\
\hline & $\mathrm{BC}-13$ & ND & Broad bean, Xian Ning (Hubei), 2007 & - & + & - \\
\hline & BC-30 & ND & Broad bean, Yi Chang (Hubei), 2007 & - & + & - \\
\hline & BG-55 & ND & Broad bean, E Zhou (Hubei), 2008 & - & + & - \\
\hline & BG-68 & ND & Broad bean, Jing Shan (Hubei), 2008 & - & + & - \\
\hline & BG-81 & ND & Broad bean, Xian Tao (Hubei), 2008 & - & + & - \\
\hline & BG-92 & ND & Broad bean, Ying Shan (Hubei), 2008 & - & + & - \\
\hline & BG-128 & ND & Broad bean, Yi Cheng (Hubei), 2009 & - & + & - \\
\hline \multirow[t]{2}{*}{ B. sinoviticola } & GBC-2b & ND & Table grape, Wuhan (Hubei), 2009 & - & - & - \\
\hline & GBC-5 & ND & Table grape, Xin Jiang, 2010 & - & - & - \\
\hline B. elliptica & LilyBC-2 & ND & Lily, Wuhan (Hubei), 2006 & - & - & - \\
\hline B. squamosa & GarBC-2 & ND & Garlic, Wuhan (Hubei), 2005 & - & - & - \\
\hline B. porri & GarBC-38 & ND & Garlic, Lai Feng (Hubei), 2007 & - & - & - \\
\hline B. sinoallii & LeeBC-18 & ND & Leek, ChongYang (Hubei), 2008 & - & - & - \\
\hline B. aclada & OniBC-15 & ND & Onion, Wuhan (Hubei), 2006 & - & - & - \\
\hline B. byssoidea & OniBC-76 & ND & Onion, Yun Xi (Hubei), 2008 & - & - & - \\
\hline \multirow[t]{2}{*}{ Botrytis sp. } & SedBC-1 & ND & Whorled stonecrop, Shi Yan (Hubei), 2010 & - & - & - \\
\hline & SedBC-2 & ND & Whorled stonecrop, Shi Yan (Hubei), 2010 & - & - & - \\
\hline Amphobotrys ricini & CopAr-5 & ND & Copperleaf, Jing Zhou (Hubei), 2008 & - & - & - \\
\hline Streptobotrys sp. & StrBC-1 & ND & Oilseed rape, Wuhan (Hubei), 2009 & - & - & - \\
\hline Alternaria alternata & $\mathrm{Za}-4$ & ND & Broad bean, Wuhan (Hubei), 2010 & - & - & - \\
\hline Arthrinium phaeospermum & Za-1 & ND & Broad bean, Wuhan (Hubei), 2010 & - & - & - \\
\hline Fusarium chlamydosporum & Za-3-3 & ND & Broad bean, Wuhan (Hubei), 2010 & - & - & - \\
\hline F. equiseti & Za-3-2 & ND & Broad bean, Wuhan (Hubei), 2010 & - & - & - \\
\hline Pestalotiopsis olivacea & Za-5 & ND & Broad bean, Wuhan (Hubei), 2010 & - & - & - \\
\hline Rhizopus sp. & Za-Rh & ND & Broad bean, Wuhan (Hubei), 2011 & - & - & - \\
\hline
\end{tabular}

a DNA markers specific to B. cinerea, B. fabae, and B. fabiopsis were amplified by PCR with the primer sets Bc-f/Bc-r (327 bp), Bfab-f/Bfab-r (613 bp), and Bfaf/Bfa-r (762 bp), respectively; + and - indicate positive and negative amplifications, respectively.

b Transposable elements Boty (533 bp) and Flipper (1,250 bp) were amplified by PCR with the primer sets BotyF4/BotyR4 and F300/F1550 (Samuel et al. 2012), respectively; vacuma $=$ no PCR detected Boty or Flipper . ND $=$ not detected. 
PCR program and the resulting PCR products were detected by agarose gel electrophoresis.

Assessment of primer performance using plant DNA. The feasibility of the primer sets for detecting the targeted Botrytis spp. in the presence of host DNA was tested in two ways. First, the fungal DNA of each targeted species was mixed in different proportions with broad bean DNA and used in a single primer set assay. Each $50-\mu l$ PCR mixture contained $5 \mu \mathrm{l}$ of $10 \times$ PCR buffer; $1 \mu l$ of dNTP mixture $(2.5 \mathrm{mM}) ; 1.25 \mathrm{U}$ of rTaq DNA polymerase (0.25 $\mu \mathrm{l}$, TaKaRa); $1 \mu \mathrm{l}$ of each primer set $(20 \mu \mathrm{M})$; and $40 \mathrm{ng}$ of DNA of a Botrytis isolate (B. cinerea $\mathrm{BC}-1$, B. fabae $\mathrm{BC}-17$, or B. fabiopsis $\mathrm{BC}-30$ ) plus broad bean DNA at $0,40,400,4,000$, or $40,000 \mathrm{ng}$; and $\mathrm{ddH}_{2} \mathrm{O}$ to $50 \mu \mathrm{l}$. One PCR mixture without any template DNA was used as the negative control. The PCR was performed using the conventional PCR program and the resulting PCR products were detected by agarose gel electrophoresis.

Then, the primer pairs were tested on DNA isolated from either artificially infected or naturally infected broad bean leaflets. To obtain artificially infected plants, 40 healthy leaflets detached from 30-day-old plants of broad bean ( $V$. faba 'Feng Dou Number 12') were placed in four rows on moisturized paper towels in an enamelware tray. Ten leaflets were inoculated with $B$. cinerea isolate $\mathrm{BC}-1$, B. fabae isolate $\mathrm{BC}-17$, or B. fabiopsis isolate $\mathrm{BC}-30$ using mycelial agar plugs (6 $\mathrm{mm}$ in diameter) removed from a 2-day-old PDA culture, one mycelial agar plug per leaflet. Ten leaflets inoculated with PDA plugs without mycelia were used as the negative inoculation control. The tray was covered with a $0.1-\mathrm{mm}$-thick transparent plastic film (Gold Mine Plastic Industry Ltd., Jiangmen, China) to maintain high humidity (approximately 100\% relative humidity) and placed in an incubator at $20^{\circ} \mathrm{C}$ under fluorescent light for $24 \mathrm{~h}$. After aseptically removing the agar plugs, leaf tissues directly underneath the agar plugs with visible necrotic lesions or for the control treatment were collected using a sterilized razor blade. DNA was extracted from the leaf sample using the Plant Genomic DNA Kit (TIANGEN) and used as template (approximately $40 \mathrm{ng}$ of DNA per reaction) in single primer set PCR as mentioned above. A PCR mixture without template DNA was treated as the negative PCR control. Meanwhile, two other primer sets, including ITS1/ITS4 (White et al. 1990) and Peter_RubisCO_down/Peter_RubisCO_up (Spring et al. 2011) in separate PCR mixtures, were included in this experiment for detecting the DNA of Botrytis and broad bean, respectively. The PCR was performed using the conventional PCR program and the resulting PCR products were detected by agarose gel electrophoresis. The DNA bands generated by the primer sets ITS1/ITS4 and Peter_RubisCO_down/Peter_RubisCO_up were individually purified from the agarose gels, cloned into $E$. coli $\mathrm{DH} 5 \alpha$, and sequenced.

To obtain naturally infected broad bean tissue, diseased leaflets of broad bean with visible chocolate spot symptoms were collected in the spring seasons of 2011, 2012, and 2013 from eight locations in
Hubei Province (Wuhan, Xian Ning, Xian Tao, Xian Feng, Xiao Gan, Tian Men, Qian Jiang, and Jing Men) and from Cheng Du of Sichuan Province. The leaflets were stored at $-20^{\circ} \mathrm{C}$ before use. A subsample of $0.1 \mathrm{~g}$ of leaf tissue was prepared from a randomly selected leaflet for each leaf sample. DNA was extracted from each subsample using the Plant Genomic DNA Kit (TIANGEN) and used as template in multiplex PCR, as mentioned above. Multiplex PCR was conducted using the conventional PCR program to generate species-specific DNA markers for each Botrytis sp., which were then separated and detected by agarose gel electrophoresis. A leaf sample was considered positive for infestation with a species of Botrytis if that leaf sample was detected to have the species-specific DNA marker for that Botrytis sp. Additionally, in order to confirm the detection result of the multiplex PCR, single PCR was used to detect Botrytis spp. in each of the 20 leaf samples collected from Wuhan of China using the DNA from each subsample as template.

\section{Results}

Botrytis spp.-specific primers. Three primer sets-namely Bc-f/ Bc-r, Bfa-f/Bfa-r, and Bfab-f/Bfab-r-were designed for B. cinerea, $B$. fabae, and $B$. fabiopsis, respectively (Table 2). The primers sets $\mathrm{Bc}-\mathrm{f} / \mathrm{Bc}-\mathrm{r}$ and $\mathrm{Bfab}-\mathrm{f} / \mathrm{Bfab}-\mathrm{r}$ were designed based on the sequences of the 354- and 964-bp-long DNA fragments, respectively, obtained in the RAPD assays. The 354-bp-long DNA fragment is 99\% identical to a DNA region in Botryotinia fuckeliana T4 SuperContig_10_1 genomic supercontig (GenBank accession number FQ790337.1). The 964-bp-long DNA fragment is $82 \%$ identical to a DNA region in B. fuckeliana T4 Supercontig_106_1 genomic supercontig (GenBank accession number FQ790361.1). The primer set Bfa-f/Bfa-r (Table 2) was designed based on the 1,364-bp-long DNA sequence of the $N E P 1$ gene cloned from $B$. fabae.

Evaluation of primer specificity. Results from both the single primer set PCR assays and the multiplex PCR assays indicated that the primer sets $\mathrm{Bc}-\mathrm{f} / \mathrm{Bc}-\mathrm{r}, \mathrm{Bfa}-\mathrm{f} / \mathrm{Bfa}-\mathrm{r}$, and Bfab-f/Bfab-r exhibited high specificity in detecting Botrytis cinerea, B. fabae, and B. fabiopsis, respectively. As expected, the primer set $\mathrm{Bc}-\mathrm{f} / \mathrm{Bc}-\mathrm{r}$ generated a 327-bp-long DNA fragment in all 29 tested isolates of $B$. cinerea from broad bean and from 21 other plant species (Table 1) but did not generate any DNA fragments from any isolates of $B$. fabae and B. fabiopsis (Figs. 1-3; Table 1). The 29 isolates of $B$. cinerea from different host plants represent a diverse collection in terms of presence or absence of the transposable elements (Boty and Flipper). There were 2, 12, and 12 isolates containing Boty, Flliper, and Boty + Flipper, respectively. Three isolates were detected to be the vacuma type without harboring any transposable elements mentioned above (Table 1).

Similarly, the primer set Bfa-f/Bfa-r generated a 762-bp-long DNA fragment in all eight tested isolates of $B$. fabae but did not generate any DNA fragments from any isolates of $B$. cinerea and

Table 2. Polymerase chain reaction primers used in this study for detection of Botrytis cinerea, B. fabae, and B. fabiopsis

\begin{tabular}{|c|c|c|c|}
\hline Primer & Sequence $\left(5^{\prime} \rightarrow 3^{\prime}\right)$ & Size (bp) & Source $^{\mathbf{a}}$ \\
\hline OPE-11 & GAGTCTCAGG & $100-3,000$ & Sangon Biotech \\
\hline OPA-13 & CAGCACCCAC & $100-3,000$ & Sangon Biotech \\
\hline Bc-f & CAGGAAACACTTTTGGGGATA & 327 & This study \\
\hline Bc-r & GAGGGACAAGAAAATCGACTAA & & \\
\hline Bfab-f & TCACGGTTTCTTGTCCATCC & 613 & This study \\
\hline Bfab-r & TCGGGCGTTGTACTCTTCAT & & \\
\hline Bfa-f & TCCTTTCTATCCTCGCTGCC & 762 & This study \\
\hline Bfa-r & CTGGTGGTTTGTAAAGCTGC & & \\
\hline ITS1 & TCCGTAGGTGAACCTGCGG & 539 & White et al. 1990 \\
\hline ITS4 & TCCTCCGCTTATTGATATGC & & \\
\hline Peter_RubisCO_down & CCAAACGTGAATACCCCCCGAAGC & 762 & Spring et al. 2011 \\
\hline Peter_RubisCO_up & GCTCTACGTCTGGAAGATTTGCGA & & \\
\hline F300 & GCACAAAACCTACAGAAGA & 1250 & Samuel et al. 2012 \\
\hline F1550 & ATTCGTTTCTTGGACTGTA & & \\
\hline BotyF4 & CAGCTGCAGTATACTGGG GGA & 533 & Samuel et al. 2012 \\
\hline BotyR4 & GGTGCTCAAAGTGTTACGGGAG & & \\
\hline
\end{tabular}

a Sangon Biotech = Sangon Biotech (Shanghai) Co., Ltd., Shanghai, China. 
B. fabiopsis (Figs. 1-3; Table 1). The primer set Bfab-f/Bfab-r generated a 613-bp-long in all eight tested isolates of $B$. fabiopsis but did not generate any DNA fragments in any of the $B$. cinerea and B. fabae isolates (Figs. 1-3; Table 1). Furthermore, all three primer sets failed to generate any DNA fragments from 10 isolates of eight other species of Botrytis, one isolate of A. ricini, one isolate of Streptobotrys, and six isolates of five other fungal genera likely occurring saprophytically on broad bean (Table 1).

PCR detection limit. The amount of template DNA greatly affected generation of the DNA marker specific to each species of Botrytis in PCR with each primer set. With a decrease of the amount of the template DNA from 40 to $0.04 \mathrm{ng}$ per reaction, the yield of the DNA markers for B. cinerea (327 bp long), B. fabae (762 bp long), and B. fabiopsis (613 bp long) was gradually decreased (Fig. 4). The PCR detection limit was $40 \mathrm{pg}$ of DNA per PCR reaction for $B$. fabae and B. fabiopsis using the primer sets Bfa-f/Bfa-r and Bfab-f/Bfab-r, respectively, whereas it was $400 \mathrm{pg}$ of DNA per reaction for $\mathrm{B}$. cinerea using the primer set $\mathrm{Bc}-\mathrm{f} / \mathrm{Bc}-\mathrm{r}$.

Feasibility of PCR detection of Botrytis spp. Three independent PCR detection experiments indicated that the three primer sets can be used to detect the three species of Botrytis in artificially infected broad bean plants. The result of the single primer set PCR experiment demonstrated that the presence of the broad bean DNA in the PCR mixtures for each species of Botrytis at ratios of $1: 1$ to 1:1000 (Botrytis DNA/broad bean DNA [wt/wt]) had little effect on generation of the species-specific markers using each primer set (Fig. 5).

In the artificial inoculation experiment, the DNA markers specific to B. cinerea, B. fabae, and B. fabiopsis were obtained in PCR with DNA from leaves inoculated with B. cinerea, B. fabae, and B. fabiopsis, respectively, using the corresponding primer sets (Fig. 6), whereas these species-specific primer sets did not generate any DNA bands with the template DNA isolated from leaves inoculated with nontargeted Botrytis spp. or with plain agar plugs. Moreover, the general primer set ITS1/ITS4 generated two DNA bands in the samples inoculated with each Botrytis spp., a 698-bp-long DNA fragment from broad bean DNA, and a 539-bp-long DNA fragment from the Botrytis DNA, but only one DNA band from broad bean DNA in the noninoculated leaves. The PCR reactions with the broad bean DNA and the specific primer set Peter_RubisCO_down/ Peter_RubisCO_up generated only the 762-bp-long DNA fragment, further confirming the result with the ITS primers. The 539-bp-long DNA fragment was $100 \%$ identical to the ITS sequences of $B$. cinerea (GenBank accession numbers EU519209 and EU519210) and B. fabiopsis (GenBank accession number EU519204). The 698-bp-long DNA fragment was 99\% identical to the ITS sequence of $V$. faba (GenBank accession number FJ212318). The 762-bp DNA fragment was 99\% identical to the gene coding for ribulose-1,5-bisphosphate carboxylase in $V$. faba (GenBank accession number JN661200).

With the 52 samples from naturally infected broad bean leaves collected from nine locations over a period of 3 years, multiplex PCR detected 4, 30, and 31 leaf samples infested with B. fabae
(7.7\%), B. fabiopsis (57.6\%), and B. cinerea (59.6\%), respectively (Table 3). At least one Botrytis sp. was detected in each sample, and some samples were coinfected by more than one Botrytis sp. Moreover, the result of the single PCR detection of the Botrytis spp. in 20 leaf samples collected from Wuhan (data not shown) confirmed

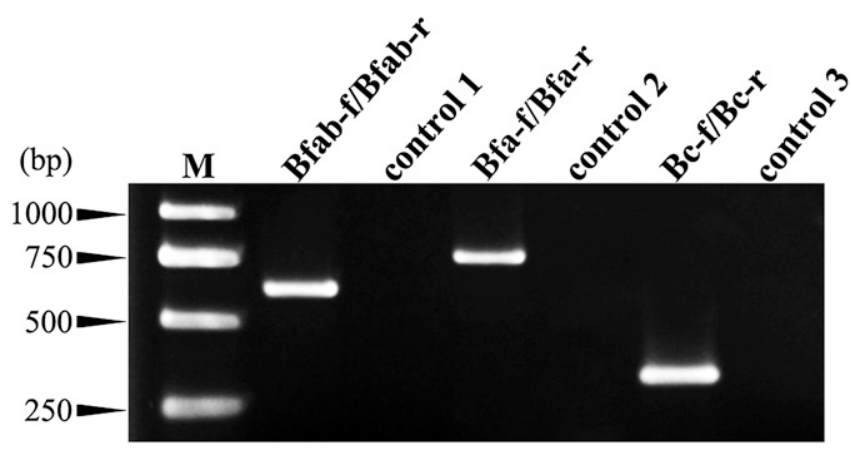

Fig. 2. Single primer set polymerase chain reaction (PCR) detection of Botrytis fabiopsis B. fabae, and B. cinerea using the species-specific primer sets Bfab-f/Bfab-r, Bfa-f/Bfa-r, and $\mathrm{Bc}-\mathrm{f} / \mathrm{Bc}-\mathrm{r}$, respectively. DNA of the three Botrytis spp. was in equal proportion and used as template in each PCR. Lane M = DL2000 DNA marker (TaKaRa); control 1 , control 2, and control 3 represent PCR containing the primer sets Bfab-f/ Bfab-r, Bfa$\mathrm{f} / \mathrm{Bfa}-\mathrm{r}$, and Bc-f/Bc-r, respectively, but without addition of any DNA template.

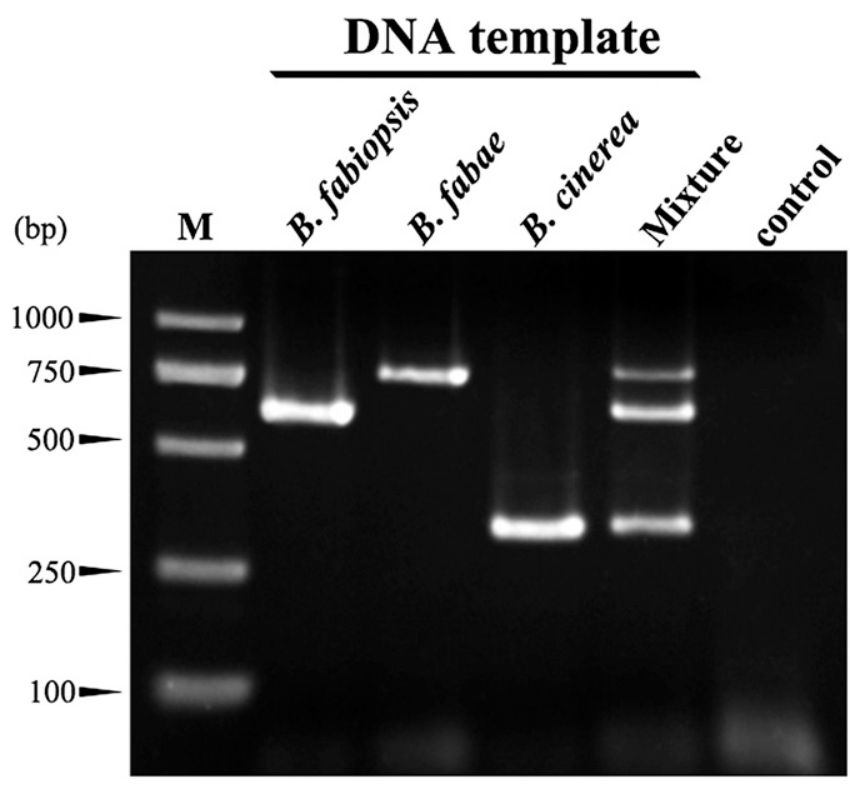

Fig. 3. Multiple primer set polymerase chain reaction (PCR) detection of Botrytis fabiopsis, $B$. fabae, and $B$. cinerea using the multiple primer sets Bfab-f/Bfab-r, Bfa-f/Bfa-r, and Bc-f/BC$r$ and the DNA template of $B$. fabiopsis, $B$. fabae, $B$. cinerea, or the mixed DNA of the three species of Botrytis (Mixture). Control = PCR without addition of any DNA template.

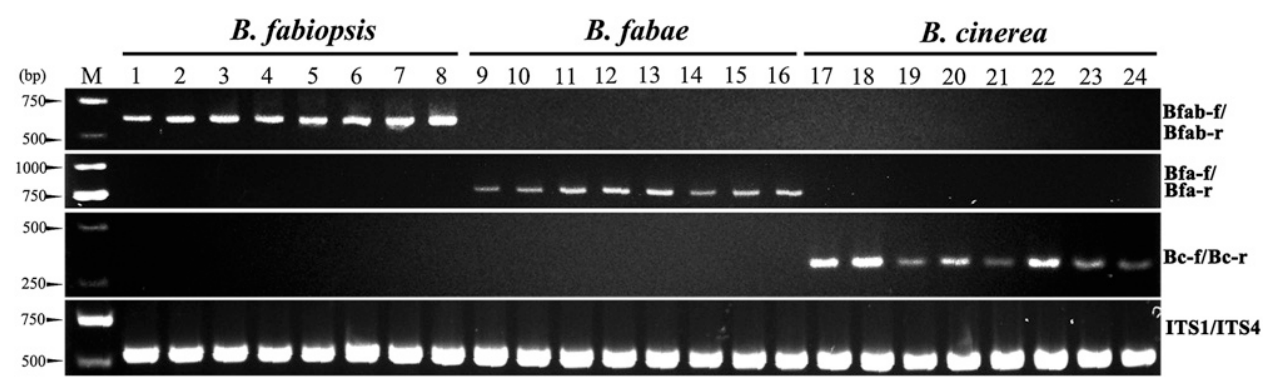

Fig. 1. Separate polymerase chain reaction amplifications detecting Botrytis fabiopsis, B. fabae, and B. cinerea using the primer sets Bfab-f/Bfab-r, Bfa-f/Bfa-r, and Bc-f/Bc-r, respectively. Note four different gels for the composite plate. Amplification of the internal transcribed spacer (ITS)-ribosomal DNA sequence for each fungal isolate using the primer set ITS1/ITS4 was used as control. Lane M: DL2000 DNA marker (TaKaRa); lanes 1 to 8: B. fabiopsis isolates BC-2, BC-13, BC-30, BG-55, BG-68, BG-81, BG-92, and BG-128, respectively; lanes 9 to 16: B. fabae isolates BC-17, BC-22, BC-25, BF-63, BF-100, BF-109, BF-120, and BF-136, respectively; lanes 17 to 24: B. cinerea isolates $\mathrm{BC}-1, \mathrm{BC}-15, \mathrm{BC}-27, \mathrm{BC}-60, \mathrm{BC}-70, \mathrm{BC}-72, \mathrm{BC}-96$, and $\mathrm{BC}-103$, respectively. 
the result of the multiplex PCR detection of those leaf samples (Table 3).

\section{Discussion}

The present study reveals that the three species of Botrytis - namely, B. cinerea, B. fabae, and B. fabiopsis - that cause chocolate spot of broad bean in China can be detected and distinguished by PCR using the species-specific primer sets Bc-f/Bc-r, Bfa-f/Bfa-r, and Bfab-f/ Bfab-r, respectively (Figs. 1-6; Table 1). Previous studies have developed PCR-based assays to detect $B$. cinerea on various hosts using species-specific primer sets (Celik et al. 2009; Chen et al. 1998; Diguta et al. 2010; Gindro et al. 2005; Mehli et al. 2005; Rigotti et al. 2002; Spotts et al. 2008; Suarez et al. 2005; Tomlinson et al. 2010), Botrytis spp. (B. aclada, B. allii, and B. byssoidea) in onion seed (Chilvers et al. 2007), and B. squamosa in onion leaves (Carisse et al. 2009). The PCR-based detection assays developed in this study will facilitate a large-scale survey of B. cinerea, B. fabae, and B. fabiopsis on broad bean and other leguminous plants, and will be useful for monitoring the epidemics of chocolate spot of broad bean in the field.

Previous studies by Chen et al. (1998) and Rigotti et al. (2002) demonstrated that the SCAR marker strategy can be used to develop specific primer sets (e.g., $\mathrm{C}_{729}{ }^{+} / \mathrm{C}_{729}{ }^{-}$and $\mathrm{BC}_{108}{ }^{+} / \mathrm{BC}_{563}{ }^{-}$) for detecting $B$. cinerea. Rigotti et al. $(2002,2006)$ showed that the primer set $\mathrm{C}_{729}{ }^{+} / \mathrm{C}_{729}{ }^{-}$may cross react with other Botrytis spp. and also may not detect all isolates of $B$. cinerea. They reported that the primer set $\mathrm{C}_{729}{ }^{+} / \mathrm{C}_{729}{ }^{-}$amplified a 0.7-kb-long DNA fragment from B. cinerea, and also amplified a 0.6-kb-long DNA fragment from B. fabae (Rigotti et al. 2002). Furthermore, Rigotti et al. (2006) showed that the primer set $\mathrm{C}_{729}{ }^{+} / \mathrm{C}_{729}{ }^{-}$detected only 26 isolates among 39 investigated isolates of $B$. cinerea under the standard condition. Because of the difficulty with the primer set $\mathrm{C}_{729}{ }^{+} / \mathrm{C}_{729}{ }^{-}$, Rigotti et al. (2006) designed another $B$. cinerea-specific primer set, $\mathrm{BC}_{108}{ }^{+} / \mathrm{BC}_{563}{ }^{-}$, based on the amplicon sequence of $\mathrm{C}_{729}{ }^{+} / \mathrm{C}_{729}{ }^{-}$. The new primer set could detect all $39 \mathrm{~B}$. cinerea isolates, producing a 360 -bp-long DNA fragment for 13 isolates that were not detected by the primer set $\mathrm{C}_{729}{ }^{+} / \mathrm{C}_{729}{ }^{-}$, in addition to a 480-bp-long fragment for the 26 isolates that were detected with the primer set $\mathrm{C}_{729}{ }^{+} / \mathrm{C}_{729}{ }^{-}$. The primer set $\mathrm{Bc}-\mathrm{f} / \mathrm{Bc}-\mathrm{r}$ developed in this study could detect all 29 investigated isolates of B. cinerea, representing both the vacuma type (without the transposable elements Boty or Flipper) and the transposa type (with transposable elements Boty, Flipper, or Boty + Flipper) (Figs. 1-3; Table 1). Moreover, it did not produce any cross reactions with the isolates of B. fabae and B. fabiopsis. It appears that the primer

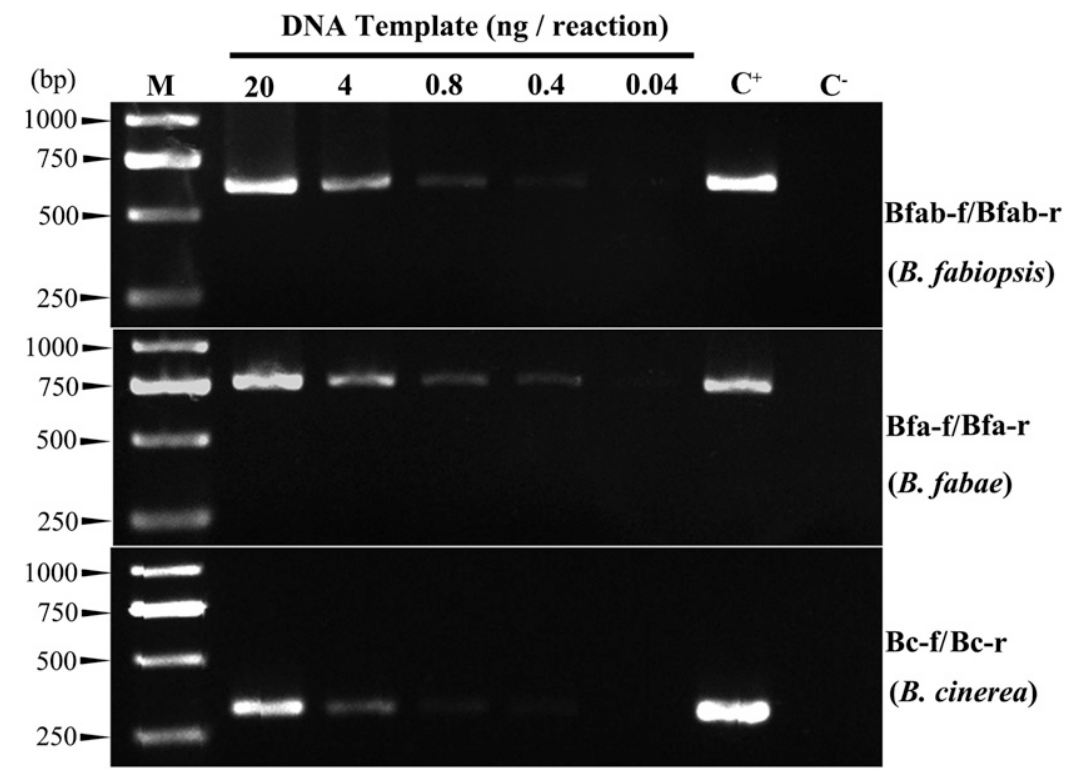

Fig. 4. Effect of the amount of template DNA on single primer set polymerase chain reaction generation of the species-specific markers for Botrytis fabiopsis, B. fabae, and $B$. cinerea. Note three different gels for the composite plate. $\mathrm{C}^{+}=$positive control with $40 \mathrm{ng}$ of template DNA per reaction and $\mathrm{C}^{-}=$negative control without template DNA. M = DL2000 DNA marker (TaKaRa).

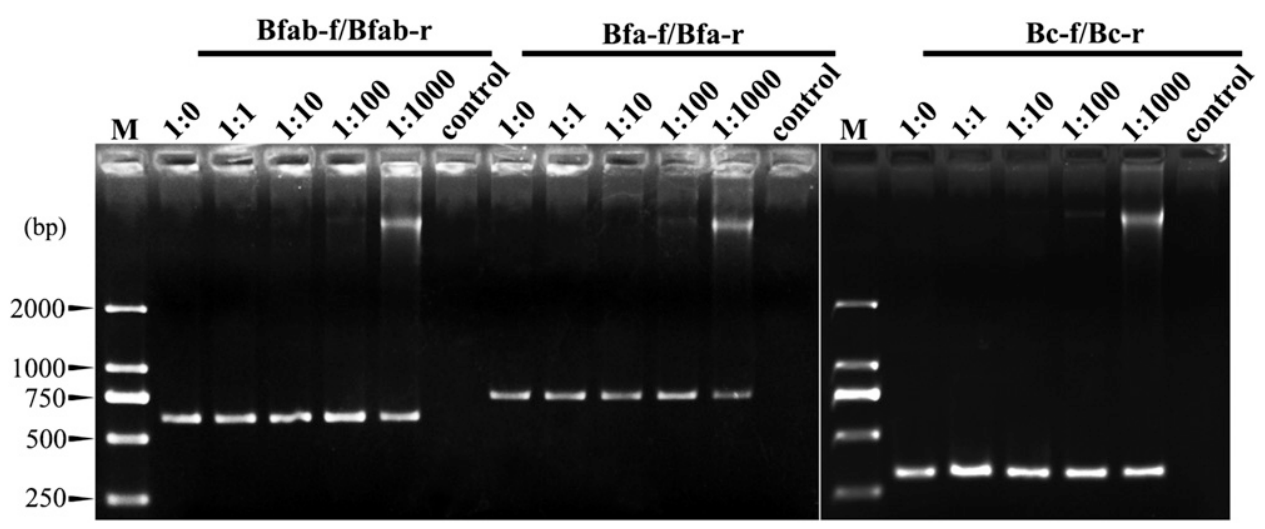

Fig. 5. Specific polymerase chain reaction (PCR) detection of Botrytis spp. in the presence of broad bean DNA. PCR with the DNA of Botrytis fabiopsis, $B$. fabae, and $B$. cinerea for generation of the species-specific PCR markers for each species of Botrytis. Note two different gels for the composite plate. Template DNA ratios of 1:0, 1:1, 1:10, 1:100, and 1:1000 represent $40 \mathrm{ng}$ of Botrytis DNA/broad bean DNA at 0,40,400,4,000, and 40,000 ng, respectively. Control = negative control without DNA template. Lane M = DL2000 DNA marker (TaKaRa). 
set $\mathrm{Bc}-\mathrm{f} / \mathrm{Bc}-\mathrm{r}$ is more efficient than the primer set $\mathrm{C}_{729}{ }^{+} / \mathrm{C}_{729}{ }^{-}$in detection of $B$. cinerea.

Another strategy for designing species-specific PCR primers is to use DNA sequences of some known nuclear genes or the nuclear ribosomal IGS region. Gene sequences coding for cutinase A, $\beta$-tubulin, and RNA helicase were previously used for designing PCR primers specific to B. cinerea (Celik et al. 2009; Gachon and Saindrenan 2004; Mehli et al. 2005; Spotts et al. 2008; Suarez et al. 2005). Diguta et al. (2010) and Tomlinson et al. (2010) used the IGS region sequences to design primers for specific detection of $B$. cinerea. Moreover, Chilvers et al. (2007) also used the IGS region to design primers for detection of B. aclada, B. allii, and B. byssoidea. Likewise, Carisse et al. (2009) used the RPB2 gene coding for RNA polymerase II as the target for detection of $B$. squamosa. In this study, the primer set Bfa-f/Bfa-r based on the NEPI sequence can be used to detect $B$. fabae (Figs. 1-6; Table 1). Use of this primer set in detection of $B$. fabae is more convenient and more efficient than the combined use of two primer sets NEP1for/NEP1revB targeting NEP1 (Staats et al. 2007) and $\mathrm{NEP}^{+} / \mathrm{NEP}^{-}$targeting NEP2 (Mirzaei et al. 2008) in detection of this fungus in our previous study (Zhang et al. 2010a).

The PCR detection limit (the least amount of template DNA required for detection in PCR reaction) is an important parameter for evaluating the feasibility of a PCR detection assay in monitoring the dynamics of $B$. cinerea and other species of Botrytis (Mehli et al. 2005). The PCR detection limit mainly depends on the copy number of the targeted DNA marker and the PCR amplification efficiency related to amplicon fragment length. Previous studies showed that the PCR detection limit varied greatly in different PCR assays using different primer sets for different Botrytis spp. For the primer set $\mathrm{C}_{729}{ }^{+} / \mathrm{C}_{729}{ }^{-}$targeting the $0.7-\mathrm{kb}$-long SCAR marker in $\mathrm{B}$. cinerea, the detection limit was approximately $0.2 \mathrm{pg}$ of DNA in a conventional PCR assay (Rigotti et al. 2002). Another conventional PCR assay by

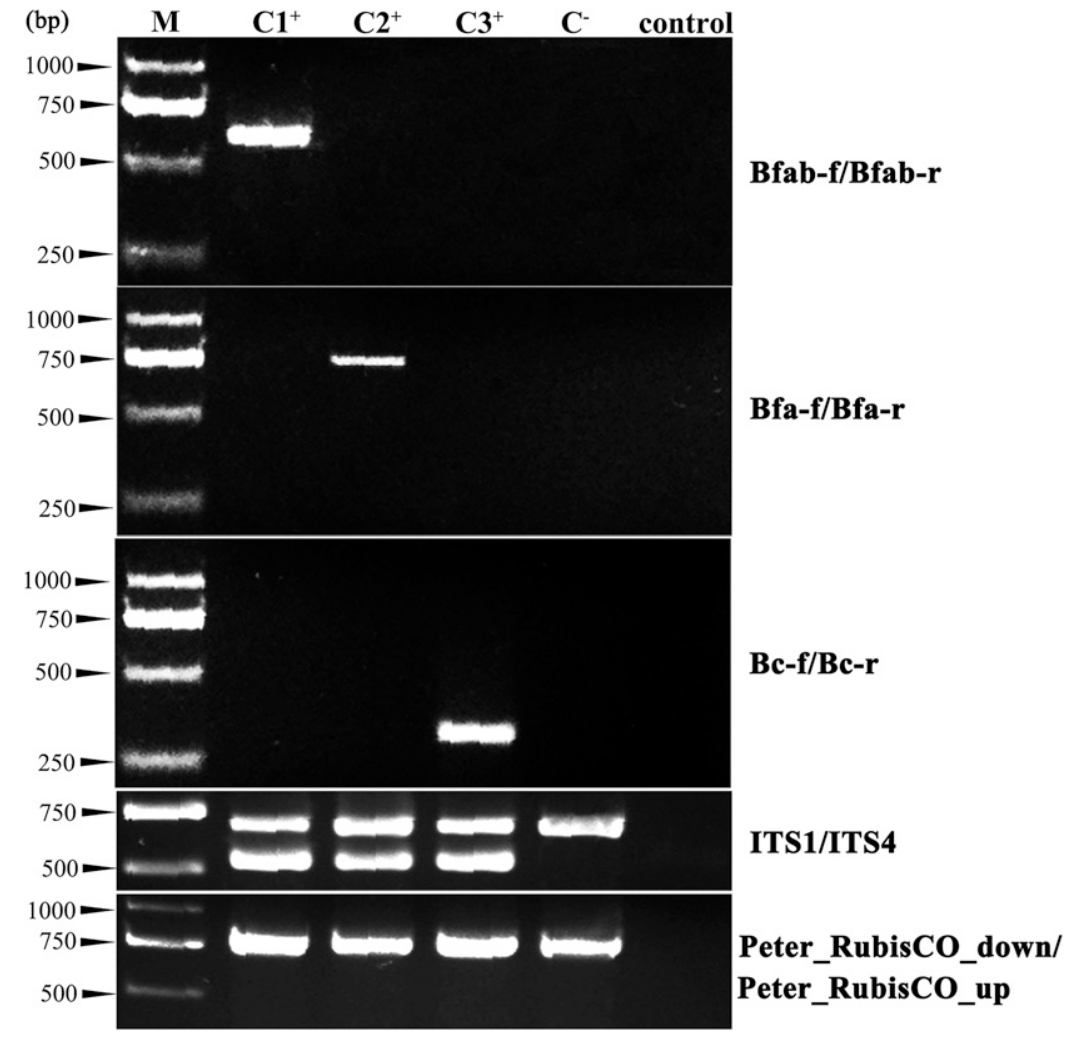

Fig. 6. Detection of Botrytis spp. in artificially inoculated broad bean leaves. Polymerase chain reaction (PCR) detection of Botrytis fabiopsis, B. fabae, and B. cinerea on leaf lesions of broad bean artificially inoculated with each fungus. Lane $\mathrm{M}=\mathrm{DL} 2000 \mathrm{DNA}$ marker (TaKaRa); $\mathrm{C1}^{+}, \mathrm{C2}{ }^{+}$, and $\mathrm{C3}^{+}$represent PCR with the template DNA extracted from broad bean leaves inoculated with $B$. fabiopsis, $B$. fabae, and $B$. cinerea, respectively; $C^{-}$represents PCR with the template DNA extracted from noninoculated broad bean leaves; control $=$ negative control without any DNA template. Primer sets are indicated on the right. The nonspecific primer set ITS1/ITS4 amplifies both broad bean DNA (top band) and Botrytis DNA (bottom band), whereas the primer set Peter_RubisCO_down /Peter_RubisCO_up is specific for broad bean DNA.

Table 3. Specific detection of Botrytis cinerea, B. fabae, and B. fabiopsis in naturally infected leave samples of broad bean showing chocolate spot symptoms using multiplex polymerase chain reaction

\begin{tabular}{|c|c|c|c|c|}
\hline \multirow[b]{2}{*}{ Source of leaf samples } & \multirow[b]{2}{*}{ Total sample number } & \multicolumn{3}{|c|}{ Number of samples tested positive for } \\
\hline & & B. cinerea & B. fabae & B. fabiopsis \\
\hline Wuhan (Hubei, 2011, 2012, 2013) & 20 & 12 & 0 & 13 \\
\hline Xian Ning (Hubei, 2012, 2013) & 13 & 11 & 0 & 4 \\
\hline Xian Tao (Hubei, 2012, 2013) & 7 & 4 & 3 & 3 \\
\hline Xian Feng (Hubei, 2012) & 2 & 0 & 1 & 2 \\
\hline Xiao Gan (Hubei, 2013) & 2 & 0 & 0 & 1 \\
\hline Tian Men (Hubei, 2013) & 2 & 0 & 0 & 2 \\
\hline Qian Jiang (Hubei, 2013) & 2 & 1 & 0 & 2 \\
\hline Jing Men (Hubei, 2013) & 2 & 1 & 0 & 1 \\
\hline Cheng Du (Sichuan, 2012) & 2 & 2 & 0 & 2 \\
\hline Total $^{\mathrm{a}}$ & 52 & $31(59.6 \%)$ & $4(7.7 \%)$ & $30(57.6 \%)$ \\
\hline
\end{tabular}

\footnotetext{
a Percentages in parenthesis were calculated by dividing the leaf samples positive for B. cinerea, B. fabae, or B. fabiopsis by the total tested leaf samples.
} 
Gindro et al. (2005) indicated that this primer set could detect the DNA from one single conidium of $B$. cinerea. For the primer set $\mathrm{Bc} 3 \mathrm{~F} / \mathrm{Bc} 3 \mathrm{R}$ targeting the multicopy IGS region of $B$. cinerea, the detection limit varied from $20 \mathrm{fg}$ to $6.3 \mathrm{pg}$ of DNA in real-time PCR assays (Diguta et al. 2010; Suarez et al. 2005). A loop-mediated isothermal amplification (LAMP) assay by Tomlinson et al. (2010) indicated that the detection limit for the six LAMP primers targeting the IGS region of $B$. cinerea was 65 pg of DNA. Moreover, Chilvers et al. (2007) reported a detection limit of $10 \mathrm{fg}$ of DNA of B. aclada and B. allii in a real-time PCR assay using the primer set LR12R/CNS1 targeting the IGS region. This study demonstrated that the PCR detection limits for $B$. fabae, B. fabiopsis, and B. cinerea were 40, 40, and $400 \mathrm{pg}$ using the primer sets Bfa-f/Bfa-r, Bfab-f/Bfab-r, and Bc-f/Bc-r, respectively (Fig. 3). These values appeared higher than those in most of the PCR assays conducted previously (Chilvers et al. 2007; Diguta et al. 2010; Gindro et al. 2005; Mehli et al. 2005; Rigotti et al. 2002; Suarez et al. 2005; Tomlinson et al. 2010). Further improvement in detection limit may be possible through optimization of the PCR ingredients and conditions or developing nested PCR assays targeting the SCAR markers established in this study and the NEP1 gene sequences cloned in previous studies (Staats et al. 2007; Zhang et al. 2010a).

B. fabiopsis is a recently described new species (Zhang et al. 2010a). Although B. fabiopsis is similar to B. fabae in conidial size and morphology, phylogenetic analyses showed that it is distantly related to $B$. fabae based on partial gene sequences of $G 3 P D H, H S P 60$, and $R P B 2$ (Zhang et al. 2010a). Isolates of B. fabiopsis showed DNA banding patterns that were very different from those observed for the isolates of $B$. fabae in the RAPD assays. This result further supports separation of $B$. fabiopsis from $B$. fabae.

Zhang et al. (2010a) reported that B. cinerea and B. fabiopsis are more widely distributed than $B$. fabae on broad bean in Hubei Province of China based on retrieval of the fungi in tissues of broad bean on PDA medium. Huang et al. (2012) reported that B. cinerea and B. fabiopsis were isolated by 32.9 and $39.5 \%$, respectively, compared with an isolation frequency of $27.6 \%$ for $B$. fabae in six other provinces in China (Chongqing, Gansu, Hebei, Jiangsu, Qinghai, and Sichuan). The present study showed that the multiplex PCR assay detected B. cinerea, B. fabiopsis, and B. fabae at 59.6, 57.6, and $7.7 \%$, respectively, in diseased leaves of broad bean (Table 3 ). The high detection frequencies for $B$. cinerea or $B$. fabiopsis but low detection frequency for $B$. fabae observed in this study are similar to the results obtained using the conventional fungal isolation method in the studies mentioned above (Huang et al. 2012; Zhang et al. 2010a). Therefore, the PCR assay is probably a reliable tool for in planta detection of B. cinerea, B. fabae, and B. fabiopsis. Further studies to optimize the multiplex PCR assay and detect airborne conidia of the three Botrytis spp. are needed to warrant the validity of using the PCR assay to monitor epidemics of chocolate spot of broad bean in the future.

In conclusion, this study developed three primer sets: Bc-f/Bc-r, Bfa-f/ Bfa-r, and Bfab-f/Bfab-r. They can be potentially used for molecular identification of B. cinerea, B. fabae, and B. fabiopsis and for monitoring the epidemics of chocolate spot of broad bean under field conditions.

\section{Acknowledgments}

This research was funded by the R \& D Special Fund for Public Welfare Industry (Agriculture) of China (grant number 201303025) and the National Natural Science Foundation of China (grant numbers 31070122 and 31301615).

\section{Literature Cited}

Carisse, O., Tremblay, D. M., Lévesque, C. A., Gindro, K., Ward, P., and Houde, A. 2009. Development of a TaqMan real-time PCR assay for quantification of airborne conidia of Botrytis squamosa and management of Botrytis leaf blight of onion. Phytopathology 99:1273-1280.

Celik, M., Kalpulov, T., Zutahy, Y., Ish-shalom, S., Lurie, S., and Lichter, A. 2009. Quantitative and qualitative analysis of Botrytis inoculated on table grapes by qPCR and antibodies. Postharvest Biol. Technol. 52:235-239.

Chen, L. C., Chen, T. Z., Chen, H. L., and Yeh, Y. 1998. Establishment of molecular markers for detection and diagnosis of Botrytis cinerea and B. elliptica. Plant Pathol. Bull. 7:177-188.

Chilvers, M. I., du Toit, L. J., Akamatsu, H., and Peever, T. L. 2007. A real-time, quantitative PCR seed assay for Botrytis spp. that cause neck rot of onion. Plant Dis. 91:599-608.
Diguta, C. F., Rousseaux, S., Weidmann, S., Bretin, N., Vincent, B., GuillouxBenatier, M., and Alexandre, H. 2010. Development of a qPCR assay for specific quantification of Botrytis cinerea on grapes. FEMS Microbiol. Lett. 313:81-87.

Gachon, C., and Saindrenan, P. 2004. Real-time PCR monitoring of fungal development in Arabidopsis thaliana infected by Alternaria brassicicola and Botrytis cinerea. Plant Physiol. Biochem. 42:367-371.

Gindro, K., Pezet, R., Viret, O., and Richter, H. 2005. Development of a rapid and highly sensitive direct-PCR assay to detect a single conidium of Botrytis cinerea Pers.:Fr in vitro and quiescent forms in planta. Vitis 44:139-142.

Gourley, C. O., and Delbridge, R. W. 1973. Botrytis fabae and Ascochyta fabae on broad beans in Nova Scotia. Can. Plant Dis. Surv. 53:79-82.

Harrison, J. G. 1988. The biology of Botrytis spp. on Vicia beans and chocolate spot disease-a review. Plant Pathol. 37:168-201.

Hennebert, G. L. 1973. Botrytis and Botrytis-like genera. Persoonia 7:183-204

Huang, Y., Duan, C. X., Lu, M., Yang, D. F., and Zhu, Z. D. 2012. Identification of the pathogens causing chocolate spot on the broad bean. Plant Prot. 38: 115-118.

Mehli, L., Kjellsen, T. D., Dewey, F. M., and Hietala, A. M. 2005. A case study from the interaction of strawberry and Botrytis cinerea highlights the benefits of co-monitoring both partners at genomic and mRNA level. New Phytol. 168:465-474.

Mirzaei, S., Goltapeh, E. M., Shams-Bakhsh, M., and Safaie, N. 2008. Identification of Botrytis spp. on plants grown in Iran. J. Phytopathol. 156:21-28.

Möller, E. M., Bahnweg, G., Sandermann, H., and Geige, H. H. 1992. A simple and efficient protocol for isolation of high molecular weight DNA from filamentous fungi, fruit bodies, and infected plant tissues. Nucleic Acids Res. 20:6115-6116

Rigotti, S., Gindro, K., Richter, H., and Viret, O. 2002. Characterization for molecular markers for specific and sensitive detection of Botrytis cinerea Pers.:Fr. in strawberry (Fragaria $\times$ ananassa) using PCR. FEMS Microbiol Lett. 209:169-174.

Rigotti, S., Viret, O., and Gindro, K. 2006. Two new primers highly specific for the detection of Botrytis cinerea Pers. Fr. Phytopathol. Mediterr. 45:253260.

Samuel, S., Veloukas, T., Papavasileiou, A., and Karaoglanidis, G. S. 2012. Differences in frequency of transposable elements presence in Botrytis cinerea populations from several hosts in Greece. Plant Dis. 96:12861290.

Soper, M. H. R. 1952. A study of the principal factors affecting the establishment and development of the field bean (Vicia faba). J. Agric. Sci. 42:335-346.

Spotts, R. A., Wallis, K. M., Serdani, M., O'Gorman, D. T., and Sholberg, P. L. 2008. Methodology for determining relationships between inoculum concentration of Botrytis cinerea and Penicillium expansum and stem end decay of pear fruit. Plant Dis. 92:451-455.

Spring, O., Marco, T., Wolf, S., and Zipper, R. 2011. PCR-based detection of sunflower white blister rust (Pustula helianthicola $\mathrm{C}$. Rost \& Thines) in soil samples and asymptomatic host tissue. Eur. J. Plant Pathol. 131: 519-527.

Staats, M., van Baarlen, P., and van Kan, J. A. L. 2005. Molecular phylogeny of the plant pathogenic genus Botrytis and the evolution of host specificity. Mol. Biol Evol. 22:333-346.

Staats, M., van Baarlen, P., Schouten, A., van Kan, J. A. L., and Bakker, F. T. 2007. Positive selection in phytotoxic proteinen coding genes of Botrytis species. Fungal Genet. Biol. 44:52-63.

Suarez, B., Walsh, K., Boonham, N., O'Neill, T., Pearson, S., and Barker, I. 2005 Development of real-time PCR (TaqMan ${ }^{\circledR}$ ) assays for the detection and quantification of Botrytis cinerea in planta. Plant Physiol. Biochem. 43:890899.

Tomlinson, J. A., Dickinson, M. J., and Boonham, N. 2010. Detection of Botrytis cinerea by loop-mediated isothermal amplification. Lett. Appl. Microbiol. 51: 650-657

Wang, N., Ma, Y. J., Dai, G. H., and Wang, Z. Z. 2007. Study on molecular diagnosis of tomato gray mould. J. Shanghai Jiaotong Univ. (Agric. Sci.). 25:50-54.

White, T. J., Bruns, T., Lee, S., and Taylor, J. 1990. Amplification and direct sequencing of fungal ribosomal RNA genes for phylogenetics. Pages 315-322 in: PCR Protocols: A Guide to Methods and Applications. M. A. Innis, D. H Gelfand, J. J. Sninsky, and T. J. White, eds. Academic Press, New York.

Wilson, A. R. 1937. The chocolate spot disease of beans (Vicia faba L.) caused by Botrytis cinerea Pers. Ann. Appl. Biol. 24:258-288.

Yu, T. F. 1945. The red-spot disease of broad beans (Vicia faba L.) caused by Botrytis fabae Sardiña in China. Phytopathology 35:945-954.

Zhang, J., Wu, M. D., Li, G. Q., Yang, L., Yu, L., and Jiang, D. H. 2010a. Botrytis fabiopsis, a new species causing chocolate spot of broad bean in central China. Mycologia 102:1114-1126.

Zhang, J., Zhang, L., Li, G. Q., Yang, L., Jiang, D. H., Zhuang, W. Y., and Huang, H. C. 2010b. Botrytis sinoallii: A new species of the grey mould pathogen on Allium crops in China. Mycoscience 51:421-431.

Zhou, Y. J., Zhang, J., Wang, X. D., Yang, L., Jiang, D. H., Li, G. Q., Hsiang, T., and Zhuang, W. Y. 2014. Morphological and phylogenetic identification of Botrytis sinoviticola, a novel cryptic species causing gray mold disease of table grapes (Vitis vinifera) in China. Mycologia 106:43-56. 